\title{
Forecasting the Demand of Honey Product for Facing Panic Buying and Stockpile in Pandemics
}

\author{
J. A. Putritamara ${ }^{1}$, R. Yuniarti ${ }^{2}$, A. E. Kusumastuti ${ }^{3}$, N. P. Sari ${ }^{4}$, M. B. Hariyono ${ }^{5}$ \\ 1,3,5 Livestock Socio-economics Department, Faculty of Animal Science, Universitas Brawijaya Indonesia \\ ${ }^{2}$ Industrial Engineering, Faculty of Industrial Engineering, Universitas Brawijaya Indonesia \\ ${ }^{4}$ Doctoral student, Faculty of Animal Science, Universitas Brawijaya Indonesia
}

\begin{abstract}
The threat on health sector has massive impacts, and one of them is on business internal management as the main factor of producers to consider design of their products. During pandemic, honey is categorized as food supplement. In a certain phase, when the demand upon honey is high, the price tends to be unstable due to an imbalance between supply and demand. Complexities of consumer during pandemics effect on food security system. Unpreparedness of the producers in facing the phenomenon of panic buying and stockpile causes scarcity. Objective of the research was forecasting the demand of honey following the second pandemic wave and supported SMEs to create adaptive strategy to face scarcity. Method of the research used secondary data and survey in the field, which was ended by FGD to decide strategy of the producer to minimize scarcity. Data analysis used MSE (Mean Squared Error) with exponential smoothing. Results of the research showed that the method of alpha exponential 5\% has minimum error, which forecast that in December 2021, the demand of propolis honey may reduce after the 2nd wave of Covid in Indonesia and approach to normal forecasting system. The accuracy with exponential method is higher and may facilitate the producers to provide products when fear contagion and panic buying take place. Contribution of analysis result toward strategy of the producers is providing estimation that maximum amount of availability increases no more than 2 times of the real demand of the consumers when panic buying occurs. The most needed strategy is setting the timeline in the projection of consumer journey. This alternative is relevant to fear contagion phenomenon because it contributes to socio-psychology of the consumers in deciding to buy supplement of honey product. Novelty of this research is examining the frequency wave of product purchase intensity of the consumer journey with Covid-19 phenomenon.
\end{abstract}

KEYWORDS: Demand, Forecasting, Honey, Panic Buying

\section{INTRODUCTION}

Complexities of global economic pillar as a result of Covid-19 pandemics affect on stability of food product prices in developing countries as in Indonesia. Unstable economic conditions have relevant to the consumer purchasing power against food products, which establish market system toward livestock products that become elastic to income, when the consumers's income increase, the consumers' demand for livestock products will increase as well, not only the primary foods as the main priority that cannot be substituted by other products, but also non-primary foods that are conditional such as honey products, which finally being the main concern of consumers as immunomodulator during pandemics. The perspective changes of consumption patterns before and during pandemics are significantly different. It triggers the dynamic of supply and demand and tobe susceptible to scarcity and price volatility, as well as the decrease in producer performance because of the decrease in production system. If it refers to the consumers' psychology toward food products assessment, there are some differences in consumption patterns toward food products, in which consumer has fear contagion. Fear contagion is an impulsive response of consumers when they feel anxious due to situations and conditions that become big issues that threaten health and the economy so as to cause a quick reaction of panic to products that are sought after by consumers when the threat comes. Consumers choose to increase honey supply because of high demand of this product during pandemics. Such significant change toward health awareness has established psychology of the consumers to increase purchasing with the concern of not being able to fulfill the product in the future because of high demand and anxiousness that the product might be too expensive along with the scarcity phenomena in the market as more consumers purchase the products and their anxieties if it is followed by the decrease of purchasing power because of crisis. The first wave of pandemics in early emergence of positive covid in March 2020 caused the consumers' anticipation become higher in the next phase, so that consumers 


\section{International Journal of Current Science Research and Review}

ISSN: 2581-8341

Volume 04 Issue 11 November 2021

DOI: 10.47191/ijcsrr/V4-i11-16, Impact Factor: 5.825

IJCSRR@ 2021

Www.ijesrr.org

increase the preventive efforts by buying honey products and minimize the risk of rising price of the honey products in the market when the demand of the products increase. Such efforts are panic responses of the consumers to buy great amount of honey products and stockpile.

The consumers start to get stockpile during pandemics due to phenomena of high covid cases, so that a governmental scenario emerges to overcome its high spread by restricting activities of the societies and even distribution of products and limiting the products that have high demand (Hall et al. 2020).

Consumers are anxious for the price change in the future due to scarcity as experienced by some livestock products, which are assumed as good qualified products to prevent the spread of covid cases. Intention to purchase during panic buying indicates the increase level of anticipation after the first wave of the increasing covid case hit Indonesia in March 2020, and based on the experience, the consumers have specific readiness in stockpile of honey products.

Based on the producers' perspective, management and inventory adjustment with external condition of the business may increase performance of the supply chain, so that the producers are still able to fulfill high demand of the consumers even though in limitedness (Branndter, et al. 2001). Honey is a perishable product, so that it challenges the producers in logistic activities, therefore, a scenario is required to anticipate the increasing demand out of the production capacity and dynamics of the logistics.

Based on the functional perspective of a product, consumers really want to get the product among other consumers who want to buy the same product, which is limited, due to the obstacle in supply chain during pandemics and high risk of the product fulfillment (Yuen, et.al, 2020; Khan, et.al, 2020; Noone, et.al, 2020). Therefore, the massive effect of pandemics are not only perceived by the producers in facing dynamics of the consumers'demand, which increase in certain phase as well as the drastic decrease of demand in certain condition that is difficult to be predicted by the producers, and as it has high challenge, then the production capacities of the producers decrease. If there is no appropriate forecast scenario in facing the dynamics of supply and high demand, then fluctuation in product prices and food sufficiency become unstable. Such change causes the market conditions are also abnormal; inequality of supply and demand not only causes scarce and expensive products, but also threatens human health, so that it requires a forecast strategy and project the demand toward honey as a trend of new necessity and become the priority of the consumer in every situation when facing the pandemics. It is due to high consumers' anxiety along with information in media that increase intensity in buying honey. The second wave of Covid-19 case in the middle of June-July 2021 in Indonesia increased the demand of herb products, for example, honey. Such increase was followed by the decrease of purchasing power, which is triggered by some factors, the hampered market activities caused the activities to meet the consumer needs for honey are also hampered. The greatest impacts were perceived by the logistics division in bound and out bound that work below the capacities due to the bureaucratic efforts of the government in inhibiting the spread of Covid-19 case. So far, the main problem of small businesses is less adaptive in facing the business dynamics because they do not have stragey of readiness for rapid business changes. As the previous research showed that most of the researchers focused on panic buying, but today, the concept is not only examined from the consumer's perspective, but also from the producer's perspective in integrating with the balance between supply and demand in dealing with price inequality during the pandemic so that the product prices keep stable. Novelty of this research is forecasting with basic customer journey that describes the behavior pattern of the honey consumers during pandemics from supply and demand frequency.

\section{RESEARCH METHOD}

This research is a case study in SMEs of honey product TRRL in Malang, which was conducted from May to August 2021 and survey, as well as the secondary data supports to observe supply and demand of the best seller honey products during pandemics, which is related to the consumer journey during pandemics to project the consumer behavior toward honey in every phase of Covid19 case in Indonesia. Method of the research used survey and ended with FGD to formulate scenario with the expert that become the priority of strategy in minimizing supply and demand imbalances as well as logistical barriers in the midst of high demand but logistics activities are not supported. Data analysis with exponential method to guarantee the forecasting of representative honey product demand so that it can be used as reference in projecting the consumer demand in the future, maximum of 6 months ahead. This is done because of massive sectoral changes that cannot be predicted in long-term in economics sudden shift era. Data analysis used exponential smoothing and result the projection output with the lowest forecast error and high projection ability, then continued with AHP analysis to formulate adaptive strategy in honey product projection when panic buying and stockpile occur. 


\section{International Journal of Current Science Research and Review}

ISSN: 2581-8341

Volume 04 Issue 11 November 2021

DOI: 10.47191/ijcsrr/V4-i11-16, Impact Factor: 5.825

IJCSRR@ 2021

www.ijcsrr.org

The forecast method with exponential smoothing is usually used for unstable data patterns or large and turbulent changes. This forecast method works just like a thermostat. If forecast error is positive, it means the actual value of demand is higher than the forecast value $(\mathrm{A}-\mathrm{F}>0)$, and automatically the exponential smoothing will increase the forecast value. On the contrary, if forecast error is negative, it means that the actual value of demand is lower than the forecast value $(\mathrm{A}-\mathrm{F}<0)$, and automatically the exponential smoothing will decrease the forecast value.

This adjustment process takes place continuously unless the forecast error is zero. The forecast using the exponential smoothing method is based on the formula below (Gaspersz, 2001).

$\mathrm{Ft}=\mathrm{Ft}-1+\alpha($ At $-1-\mathrm{Ft}-1)(2)$

Notes

Ft : forecasting value for the-t period

Ft-1 : forecasting value for the last period, $t-1$

At-1 : actual value for the last period, $\mathrm{t}-1$

$\alpha \quad$ : smoothing constant

The method used to find out how far the reliability of the forecasting model is based on exponential smoothing should use the tracking signal control map and compare whether the forecast values reflect or match the historical pattern of the actual data of demand (Gaspersz, 2001).

The second analysis is AHP (Analytical Hierarchy Processes), which is intended to determine strategy of priority in dealing with imbalances in supply and demand for honey. The Analytical Hierarchy Processes (AHP) is a general theory to measure priority. Scales used in the measurement include nominal, ordinal, interval, and ratio scales. AHP provides solutions for measurement that could not be conversed from low scales into high scales or from ordinal category and nominal scales. AHP provides solutions for measurement that cannot be conversed from low scales into high scales or from ordinal category to nominal scales. Saaty (2001) suggested that AHP is intended to decrease ratio scales from discrete and continuous pairwise comparisons obtained from measurements of actual, relative, and priority degrees of preference and importance. AHP assists to converse measurements, which are difficult to be measured such as opinion, likes, and beliefs. AHP emphasizes the hierarchical structure of the problem as desired by the researcher. The hierarchy comprises of the main purpose, criteria and sub criteria with various alternatives that become content of the research. The result of pairwise comparisons in the form of a ratio scale into the main vector or eigen-function that can create a matrix with a positive character or reverse character, namely aij = 1/ aji. (Saaty, 2001).

\section{RESULT AND DISCUSSION}

The observation process was conducted through an in-depth study process on the increase in cases of covid using 6-month reference during the first wave of covid case in March 2020 and observation on the increase cases in June 2021. This parameter is used as basis for observing the consumer journey in passing through issues of the increase cases of Covid-19, which is followed by drastical increase of demand that so-called panic buying phenomenon, which leads to stockpile. It is intended to identify the dynamics of supply and demand when changes occur rapidly. Based on information in the field, it showed significant difference in honey consumption pattern, before and after pandemics. The demand increases during pandemics, but in certain phases, it tends to decrease on some products that tend to be expensive. TRRL offers derivative of honey products, bee pollen, and propolis. The observation focuses on 1 product that increases in demand during pandemics, namely propolis infection. Propolis infection from TRRL is almost similar to other propolis, but the consumers assume that propolis infection is more effective efficacious than other brands in increasing stamina and assisting in recovery of the Covid-19 patients, so that the demand for this product increases significantly during pandemics. In general, the offered price for propolis infection is more expensive than other products, in which $15 \mathrm{ml}$ propolis infection honey costs IDR 235,000. High demand during pandemics, particularly when the the second wave of Covid-19 increased at the end of June 2021, the producers strived to fulfill some significant needs, but certain segment groups stop buying because the purchasing power decrease, so that producers provided smaller size, $5 \mathrm{ml}$, which cost IDR 172,000,-.

Panic Buying relates to the consumers' fear as they cannot afford to buy the product they need. Therefore, it is presumed that the product is unavailable because of high demand as the problem correlates with health threats, which restrict personal freedom (for example, prevent or reduce access to the product) (Maghsoudi, et.al, 2018). Demand uncertainty that is difficult for producers to predict during a pandemic that causes supply and demand imbalances and low continuity level of the consumers in buying the 


\section{International Journal of Current Science Research and Review}

ISSN: 2581-8341

Volume 04 Issue 11 November 2021

DOI: 10.47191/ijesrr/V4-i11-16, Impact Factor: 5.825

IJCSRR @ 2021

WwW.ijcsrr.org

product because the purchasing power decreases are the reasons of the researcher to assist SMEs sector in gaining adaptive strategies forecasting of exponential smoothing.

Consumers got experiences in the first wave of Covid-19 case when the needed products were not available in the market. The consumers assume that if the positive case increase higher, so that the chance of restricting the movement of goods will increase, and of course, the producers are affected and the risk of inventory delays in the supply chain also increases, so that it can reduce product availability causing more frequent stock outs (susceptible to scarcity) (Chua et.al, 2021).

Results of analysis will be used by the experts as basis in making strategy. The table below shows the analysis results of exponential smoothing, which is examined on the forecasting purchases in 1 year from January 2021 to December 2021, the forecast is concentrated after the pandemic wave hit Indonesia.

Table 1. Forecasting the Demand of Propolis Infection on TRRL in 2021

\begin{tabular}{|l|l|l|}
\hline Month & Demand & Forecasting \\
\hline January & 250 & - \\
\hline February & 300 & 250 \\
\hline March & 340 & 275 \\
\hline April & 450 & 308 \\
\hline May & 375 & 379 \\
\hline June & 550 & 377 \\
\hline July & 850 & 464 \\
\hline August & 820 & 662 \\
\hline September & 700 & 741 \\
\hline October & 700 & 720 \\
\hline November & 670 & 710 \\
\hline December & - & 690 \\
\hline
\end{tabular}

Table 1 presents comparison between real demand and forecasting the purchase of propolis infection honey in 1 year. The analysis uses smoothing alpha $1 \%$ to assist producers increasing accuracy the amount of demand to avoid high imbalances in supply and demand for honey during pandemics. The table below presents error calculation in exponential analysis.

Table 2. Error calculation for the demand of propolis infection honey by the method of exponential smoothing alpha $1 \%$

\begin{tabular}{|c|c|c|c|c|c|}
\hline Month & Demand & Forecasting & Error & $\begin{array}{l}\text { Absolute } \\
\text { Error }\end{array}$ & Error $^{2}$ \\
\hline January & 250 & - & & & \\
\hline February & 300 & 250 & 50 & 50 & 2500 \\
\hline March & 340 & 275 & 65 & 65 & 4225 \\
\hline April & 450 & 308 & 142 & 142 & 20164 \\
\hline May & 375 & 379 & -4 & 4 & 16 \\
\hline June & 550 & 377 & 173 & 173 & 29929 \\
\hline July & 850 & 464 & 386 & 386 & 148996 \\
\hline August & 820 & 662 & 158 & 158 & 24964 \\
\hline September & 700 & 741 & -41 & 41 & 1681 \\
\hline October & 700 & 720 & -20 & 20 & 400 \\
\hline November & 670 & 710 & -40 & 40 & 1600 \\
\hline December & - & 690 & & & \\
\hline Total & & & & 1.079 & 204.564 \\
\hline Mean & & & & 107,9 & $20.454,6$ \\
\hline
\end{tabular}




\section{International Journal of Current Science Research and Review}

ISSN: 2581-8341

Volume 04 Issue 11 November 2021

DOI: 10.47191/ijcsrr/V4-i11-16, Impact Factor: 5.825

IJCSRR@ 2021

Www.ijesrr.org

Based on error analysis results, they indicate errors in forecasting amount of the demand for propolis infection honey by the producers in certain months related to health threats due to pandemics, when Covid-19 cases in Indonesia increase. Mean absolute error (MAE) is 107.9 and Mean Squared Error (MSE) is 20,454.6. The values show that forecasting the demand of propolis infection honey using exponential smoothing method $\alpha 0.5$ in December 2021 will be 690 honey products. The exponential approach assists the producers to forecast the demand by minimizing the error up to $5 \%$, it is due to many factors that cause rapid changes in consumer behavior in every month, which is synchronized with the increase number of Covid-19 cases in Indonesia. Fear contagion causes inaccurate prediction of the producer, so that the forecasting could not approach the real value of the demand. From Feruary to March 2021, stability was observed between demands and forecasting by error level not more than 100. Measurement using exponential alpha 5\% minimizes the error level and emphasizes on accuracy between the amount of demands and forecasting. The highest error values were found in June, July, and August, which were relevant to the Covid cases in Indonesia, so that during these months, panic buying and fear contagion occurred that caused high demand for propolis infection honey and it could not be fulfilled due to high difference with the forecasted values, and more producers get ready with such imbalances between the real demands and the forecasted ones, and it is susceptible to raise the product price. There was a gap between the amount of demands and the forecasting ones with 2 times the number of forecasts, so that the forecast may provide a gap for producers to continue to see the developing issues and consumer behaviors during uncertainty that cause imbalance in supply and demand. Forecasting for December 2021, a decrease may occur, in comparison with the previous months, which is relevant to the decrease of Covid-19 along with the vaccine target in Indonesia, and it enables the producers to meet the quantity of honey products around 690.

The consumer experiences in facing scarcity for short-term products due to fear contagion against price, which is caused by scarcity, have made their financial getting bloated because of high prices. Resources scarcity has made the consumers substitute it with other product and turn their attention to scarce resources (namely, tunneling) and far from other resources (Mullainathan and Shafir 2013; Zhu et al. 2018). Consumers, who have a limited budget and abundant needs, choose to use strategy which collects products to meet their needs in long-term (Shah et al. 2012). In short-term, due to resources scarcity focuses consumers' attention on their most pressing needs today, long-term goals such as savings are not a priority (Karlan et al. 2016)

The phenomena of panic buying and fear contagion have made the producers immediately switch in arranging new strategies based on consideration of the results of exponential forecasting analysis as an effort to improvise a more resilient business.

The strategy is suggested through optimization of internal business improvement that based on external business. In order to make the business to be adaptive with uncertain condition and face the consumers who have dynamic behaviors, so that the producers must focus on the issues being faced by market segmentation, so that strategy, which is designed by the expert in this research, is mapping consumer journey. It is also supported by results of the forecasting, which show that stockpile, panic buying, and fear contagion are caused by phenomena that take place in society.

Customer journey map is a process or time series of the consumers that relate to how far the consumers are involved in activities to represent in the form of interaction with producers, brands, environment, and management (Addis, 2016). Elements in consumer journey comprise of: (Bernard and Andritsos, 2017)

a. Impressive is consumers' experiences when they get the products or services.

b. Timeline is time series that belong to the consumers from initial process of knowing the brand to touchpoint with the producers (time funneling strategy).

c. Touchpoint is a process of the consumers in interacting with producers. Touchpoints can be non-linear cycles because consumers could turn to the same touchpoint repeatedly or customers may not pass through the whole touchpoint cycles, they may pass through some touchpoints and end their journeys.

d. Channel is an interaction method or channel chosen by the customers to communicate and touchpoint.

e. Emotion is sentimental level of the consumers when they get the experiences. There are 3 emotion aspects that could identify their experiences' response such as emotion, positive and negative responses, as well as customer's quotes to represent the consumers' experiences.

Table below represents the analysis results of AHP chosen by the expert to set the priorities of mapping consumer journey in TRRL to minimize the supply and demand imbalances. 


\section{International Journal of Current Science Research and Review}

ISSN: 2581-8341

Volume 04 Issue 11 November 2021

DOI: 10.47191/ijcsrr/V4-i11-16, Impact Factor: 5.825

IJCSRR@ 2021

www.ijcsrr.org

Table 3. AHP Perspective Analysis of Mapping Consumer Journey

\begin{tabular}{|l|l|l|l|l|l|l|}
\hline & Impressive & Timeline & Touch Point & Channel & Emotion & Factor Priority \\
\hline Impressive & 1 & 0,2 & 3 & 0,33 & 0,33 & 0,505 \\
\hline Timeline & & 1 & 5 & 5 & 1 & 2,375 \\
\hline Touchpoint & & & 1 & 0,33 & 0,33 & 0,317 \\
\hline Channel & & & & 1 & 1 & 0,990 \\
\hline Emotion & & & & & 1 & 1,318 \\
\hline
\end{tabular}

Based on AHP analysis results, it showed that the highest score in factor priority, which become the main assessment of the experts is timeline with the score 2.375. It indicates that in engagement strategy, timeline dominates and requires main priority to support the forecasting accuracy of propolis infection honey product. Punctuality to meet the product with the issues in society is a unit that is the main consideration for consumers in determining products which are consumed by society who do stockpiling. On timeline aspect, producers will be easier to examine the consumer behaviors at any time and compare it with panic buying and stockpile. Scarcity is a threat for consumer, which actually stimulate consumers to do stockpile and affect the supply chain. Lack of accessibility for the consumers to reach the product becomes a challenge for producers to fulfill the product in the midst of both limitations (Grier dan Davis 2013). The consumers' previous experiences in reaching the products, which relate to scarcity aspect of the product that could effect on behavior to purchase in the future (for example, individual who face limited product supply will anticipate his or her needs based on the previous experiences) (Cannon et al. 2018).

Marketing research is frequently started from two perspectives: consumers may choose the product as they want and they have sufficient resources to purchase. However, most of the consumer journeys were restricted by product and/or resources scarcities. Marketing, psychological, economic, and sociological aspects are the integrative framework that describes how the individual consumer faces such scarcities in diverse steps of their journeys (Hamilton, 2018).

\section{CONCLUSION AND RECOMENDATION}

Forecasting with exponential method has high accuracy and even assist the producer of TRRL to project the demand of propolis honey product, 2 times than normal demand, when panic buying and stockpile occur. Timeline aspect is a strategic step of the expert by setting the exponential calculation basis as a process to build tactic in facing the stockpile. Timeline may assist the producers to arrange consumer behavior toward the product at any time. It will become the producers' agenda to design more resilient business due to preparedness is arranged from the consumer journey.

\section{ACKNOWLEDGMENTS}

Special gratitude to Research Institution and Community Service (LPPM) for research grants through the scheme of HPP (Novice Researcher Grants) in 2021, and special thanks to CV TRRL for the cooperation in supporting activities of the research to achieve resilient small businesses.

\section{REFERENCES}

1. Addis, M. 2016. Understanding the Customer Journey to Create Excellent Customer Experiences in Bookshops. International Journal of Marketing Studies, 8(4), 20-36. DOI 10.5539/ijms.v8n4p20

2. Bernard, G., \& Andritsos, P. 2017. A Process Mining Based Model for Customer Journey Mapping. CAiSE 2017 Forum and Doctoral Consortium Papers, 48-56.

3. Cannon, C., Goldsmith, K., \& Roux, C. 2018. A self-regulatory model of resource scarcity. Journal of Consumer Psychology, forthcoming.

4. Chua, G.; Yuen, K.F.; Wang, X.; Wong, Y.D. The Determinants of Panic Buying during COVID-19. Int. J. Environ. Res. Public Health 2021, 18, 3247. https://doi.org/10.3390/ ijerph18063247

5. Saaty, T.L. 2001. Decision Making For Leaders. Forth edition, University of Pittsburgh, RWS Publication 


\section{International Journal of Current Science Research and Review}

ISSN: 2581-8341

Volume 04 Issue 11 November 2021

DOI: 10.47191/ijesrr/V4-i11-16, Impact Factor: 5.825

IJCSRR@ 2021

www.ijesrr.org

6. Gaspersz, V. 2001. Production Planning and Inventory Control-Berdasarkan Pendekatan Sistem Terintegrasi MRP II dan JIT Menuju Manufakturing 21. Jakarta: PT Gramedia Pustaka Utama.

7. Grier, S., \& Davis, B. (2013). Are all proximity effects created equal? Fast food near schools and body weight among diverse adolescents. Journal of Public Policy \& Marketing, 32, 116-128.

8. Hamilton, R., Thompson, D., Bone, S. et al. The effects of scarcity on consumer decision journeys. J. of the Acad. Mark. Sci. 47, 532-550 (2019). https://doi.org/10.1007/s11747-018-0604-7

9. Karlan, D., McConnell, M., Mullainanthan, S., \& Zinman, J. 2016. Getting to the top of mind: how reminders increase saving. Management Science, 62, 3393-3411

10. Khan, J.Z.; Ali, I.; Hassan, Z. Repurposed Drugs Against COVID-19: Safety Concerns and Stockout. Hosp. Pharm. 2020, 55, 218-219. [CrossRef] [PubMed]

11. Maghsoudi, A.; Zailani, S.; Ramayah, T.; Pazirandeh, A. Coordination of Efforts in Disaster Relief Supply Chains: The Moderating Role of Resource Scarcity and Redundancy. Int. J. Logist. Res. Appl. 2018, 21, 407-430. [CrossRef]

12. Noone, B.M.; Lin, M.S. Scarcity-Based Price Promotions: How Effective are they in a Revenue Management Environment? J. Hosp. Tour. Res. 2020, 44, 883-907. [CrossRef]

13. Shah, A. K., Mullainathan, S., \& Shafir, E. 2012. Some consequences of having too little. Science, 338, $682-685$.

14. Yuen, K.F.; Wang, X.; Ma, F.; Li, K.X. The Psychological Causes of Panic Buying Following a Health Crisis. Int. J. Environ. Res. Public Health 2020, 17, 3513. [CrossRef]

Cite this Article: J. A. Putritamara, R. Yuniarti, A.E. Kusumastuti, N.P. Sari, M.B. Hariyono (2021). Forecasting the Demand of Honey Product for Facing Panic Buying and Stockpile in Pandemics. International Journal of Current Science Research and Review, 4(11), 1596-1602 